\title{
Fungicide sensitivity of Mycosphaerella graminicola (Septoria tritici) isolates
}

\author{
Wrażliwość na fungicydy izolatów Mycosphaerella graminicola \\ (Septoria tritici)
}

\author{
Katarzyna Pieczul*, Ilona Świerczyńska
}

\begin{abstract}
Summary
Septoria blotch of wheat caused by Mycosphaerella graminicola (anamorph Septoria tritici) is one of the most serious disease of cereals in Poland. Fungicides from different chemical groups have been registered for the pathogen control. The aim of the study was to evaluate the sensitivity level of $M$. graminicola isolates to active substances of selected fungicides, used in the cereal crop protection. The study was performed under the laboratory condition, by analyzing the impact of active substances for M. graminicola colony linear growth inhibition. The fungicides such as triazoles, strobilurines, prochloraz, cyprodinil, and fenpropimorph greatly limited growth of M. graminicola isolates. Only thiophanate-methyl and carbendazim did not lessen growth of the tested isolates. The results indicate the possibility of effective control of septoria blotch of wheat by fungicides containing the tested active substances, except benzimidazole.
\end{abstract}

Key words: Mycosphaerella graminicola; sensitivity to fungicides

\section{Streszczenie}

Grzyb Mycosphaerella graminicola (anamorfa Septoria tritici) wywołujący septoriozę paskowaną liści pszenicy należy w Polsce do najpoważniejszych patogenów zbóż. Do zwalczania choroby zarejestrowane zostały fungicydy, należące do różnych grup chemicznych. Celem badań była ocena wrażliwości izolatów M. graminicola na substancje czynne wybranych fungicydów, stosowanych w ochronie zbóż. Badania wykonano w warunkach laboratoryjnych, analizując wpływ w/w substancji na hamowanie wzrostu liniowego kolonii izolatów M. graminicola. Większość badanych substancji czynnych z grup: triazoli, strobiluryn, prochloraz, cyprodinil oraz fenpropimorf bardzo dobrze ograniczała wzrost badanych izolatów $M$. graminicola. Jedynie tiofanat metylu oraz karbendazym nie ograniczały wzrostu badanych izolatów. Wyniki wskazują na możliwość skutecznego ograniczania septoriozy paskowanej liści pszenicy większością fungicydów zawierających testowane substancje czynne z wyłączeniem benzimidazoli.

Słowa kluczowe: Mycosphaerella graminicola; wrażliwość na fungicydy

Instytut Ochrony Roślin - Państwowy Instytut Badawczy

Zakład Mikologii

Władysława Węgorka 20, 60-318 Poznań

*corresponding author: k.pieczul@iorpib.poznan.pl 


\section{Wstęp / Introduction}

Septorioza paskowana liści pszenicy wywoływana przez Mycosphaerella graminicola (Fuckel) Schrot (anamorfa Septoria tritici Rob. ex Desm.) jest jedną z powszechnie występujących i jednocześnie najgroźniejszych chorób zbóż, głównie pszenicy i pszenżyta (Eyal 1999). W ostatnich dwudziestu latach obserwowany jest wzrost nasilenia występowania $M$. graminicola w Europie Zachodniej (Eriksen i Munk 2003) oraz w Polsce (Głazek i Sikora 1998; Mirzwa-Mróz i wsp. 2005). Pierwotnym źródłem zakażenia roślin są roznoszone przez wiatr zarodniki workowe (askospory). Pierwsze objawy chorobowe w postaci jasnych plam na liściach pojawiają się na zbożach ozimych już jesienią. Wiosną i latem plamy ciemnieją, ulegają powiększeniu często zlewając się w pasma, obejmujące niejednokrotnie znaczną powierzchnię liści. Cechą charakterystyczną są powstające w obrębie plam piknidia, a następnie pseudotecja grzyba, stanowiące miejsce wytwarzania licznych zarodników konidialnych oraz workowych, będących źródłem kolejnych infekcji. Choroba prowadzi do przedwczesnego zamierania liści, co negatywnie wpływa na ilość i jakość wytwarzanego ziarna (Eriksen i Munk 2003; Suffert i wsp. 2011). Septorioza paskowana liści pszenicy może powodować straty w plonie pszenicy sięgające kilkudziesięciu procent. W sprzyjających warunkach pogodowych choroba rozwija się bardzo szybko, przez co uprawy wymagają intensywnej ochrony chemicznej (Eyal 1999). Do zwalczania septoriozy paskowanej liści pszenicy wykorzystywane są fungicydy o szerokim spektrum grzybobójczym, należące do różnych grup chemicznych (m.in.: triazoli, strobiluryn, morfolin, benzimidazoli). Zazwyczaj służą one zwalczaniu także innych chorób liści, jak: mączniak prawdziwy zbóż i traw, rdza brunatna pszenicy, septorioza plew pszenicy.

M. graminicola należy do patogenów, które dość szybko nabywają odporność na stosowane substancje czynne fungicydów (FRAC 2013). Większość doniesień o szczepach odpornych na fungicydy pochodzi jednak z krajów Europy Zachodniej, gdzie od lat prowadzona jest intensywna ochrona upraw.

Celem badań była ocena wrażliwości krajowych izolatów $M$. graminicola na wybrane substancje czynne wchodzące w skład fungicydów stosowanych w zwalczaniu septoriozy paskowanej liści pszenicy.

\section{Materiały i metody / Materials and methods}

\section{Izolaty}

Próby naturalnie porażonej pszenicy i pszenżyta zbierane były na polach znajdujących się w miejscowościach: Baborówko, Borowo, Jarosławiec, Pawłowice, Radostowo oraz Winna Góra, w latach 2012-2013. Izolacji kultur grzybów dokonywano ze świeżego materiału roślinnego. $\mathrm{Z}$ porażonych liści wycinano fragmenty o powierzchni $0,25 \mathrm{~cm}^{2}$, które odkażano powierzchniowo w wybielaczu ACE (Procter \& Gamble; podchlorynu sodu $<5 \%$, węglan sodu $<5 \%$, wodorotlenek sodu $<1 \%$ ) przez 30 s. Po odkażeniu skrawki płukano dwukrotnie w sterylnej wodzie destylowanej, suszono ręcznikiem papierowym i wykłada- no na pożywkę WA (wodny agar). Po 2-5 dniach inkubacji $\mathrm{w}$ temperaturze pokojowej (około $22-25^{\circ} \mathrm{C}$ ) z piknidiów grzyba, za pomocą igły preparacyjnej pobierano zarodniki konidialne i sporządzano $\mathrm{z}$ nich wodną zawiesinę, którą rozprowadzano na płytce Petriego zawierającej pożywkę PDA (Potato Dextrose Agar, Difco). Wyrastające, jednozarodnikowe kolonie grzybów o cechach morfologicznych M. graminicola przeszczepiano na nową pożywkę PDA. Identyfikacji gatunkowej uzyskanych izolatów dokonywano na podstawie cech morfologicznych grzybni oraz zarodników konidialnych.

\section{Badania wrażliwości na substancje czynne fungicydów}

Do badań wytypowano 66 izolatów $M$. graminicola 43 z pszenicy i 23 z pszenżyta. Badania wrażliwości każdego z izolatów na substancje czynne wybranych fungicydów wykonano przez wyszczepienie fragmentów pożywki PDA (o powierzchni $0,25 \mathrm{~cm}^{2}$ ) przerośniętych 2-tygodniową grzybnią, na pożywkę PDA zawierającą substancje czynne (Sigma) w stężeniu 1, 3 i 10 ppm, które przed dodaniem do pożywki zostały rozpuszczone w metanolu w stężeniu $5 \mathrm{mg} / \mathrm{ml}$. W badaniach wykorzystano następujące substancje: karbendazym, tiofanat metylu (benzimidazole), prochloraz (imidazol), epoksykonazol, cyprokonazol, flusilazol, tebukonazol, tetrakonazol (triazole), fenpropimorf (morfolina), cyprodinil (anilino-pirymidyna), azoksystrobinę, krezoksym metylu i piraklostrobinę (strobiluryny). Kontrolę stanowiły kolonie grzyba rosnące na czystej pożywce PDA. Po 14 dniach inkubacji w temperaturze pokojowej (około $22-25^{\circ} \mathrm{C}$ ) izolaty mierzono i obliczano procentowy stopień hamowania ich wzrostu przez substancje czynne obecne w podłożu w stosunku do kontroli. W badaniach przyjęto następujące oznaczenia: 0 - izolaty bardzo wrażliwe, brak wzrostu, 1 - wrażliwe (1-20\% wzrostu w stosunku do średnicy kolonii kontrolnej), 2 średnio wrażliwe (21-50\%), 3 - odporne (51-80\%), 4 wysoce odporne (> 81\%). Doświadczenie wykonano w 2 niezależnych powtórzeniach, a wyniki pomiarów uśredniono. Do porównania średniego stopnia wrażliwości izolatów na badane fungicydy zastosowano analizę wariancji i wielokrotny test Tukeya przy poziomie istotności 0,05 .

\section{Wyniki i dyskusja / Results and discussion}

Przeprowadzone badania pozwoliły na ocenę stopnia wrażliwości izolatów $M$. graminicola zebranych w większości na terenie województwa wielkopolskiego na wybrane substancje czynne fungicydów. W przeprowadzonej analizie statystycznej zbadano jednorodność wariancji badanych fungicydów. Do porównania fungicydów pod względem stopnia wrażliwości zastosowano analizę wariancji i wielokrotny test Tukeya przy poziomie istotności 0,05 . W badaniu jednorodności wariancji (test Bartletta chikwadrat $=13,39, \mathrm{df}=12, \mathrm{p}=0,34)$ stwierdzono, że są one jednorodne. $\mathrm{Z}$ przeprowadzonej analizy wariancji (test $\mathrm{F}=$ 13,07 , df $=12$ i 26, p < 0,001) wynikło istotne zróżnicowanie średnich wartości wrażliwości izolatów M. graminicola na badane substancje (tab. 1). 
Tabela 1. Stopień wrażliwości izolatów Mycosphaerella graminicola na fungicydy i wyniki testu Tukeya dla $\alpha=0,05$

Table 1. Level of Mycosphaerella graminicola isolates sensitivity to fungicides and Tukey test results for $\alpha=0.05$

\begin{tabular}{|c|c|c|c|c|c|c|c|c|}
\hline \multirow{3}{*}{$\begin{array}{l}\text { Fungicyd } \\
\text { Fungicide }\end{array}$} & \multirow{3}{*}{$\begin{array}{l}\text { Stężenie substancji } \\
\text { czynnej } \\
\text { The concentration } \\
\text { of active substance } \\
\text { [ppm] }\end{array}$} & \multicolumn{5}{|c|}{$\begin{array}{c}\text { Izolaty - Isolates } \\
{[\%]}\end{array}$} & \multirow{3}{*}{$\begin{array}{l}\text { Średni stopień } \\
\text { wrażliwości } \\
\text { izolatów } \\
\text { Mean sensitivity } \\
\text { isolates level }\end{array}$} & \multirow{3}{*}{$\begin{array}{c}\text { Wyniki } \\
\text { testu } \\
\text { Tukeya } \\
\text { Tukey tes } \\
\text { results }\end{array}$} \\
\hline & & \multicolumn{5}{|c|}{ stopień wrażliwości - sensitivity level } & & \\
\hline & & 0 & 1 & 2 & 3 & 4 & & \\
\hline \multirow{3}{*}{ Carbendazim } & 1 & 0,0 & 0,0 & 1,5 & 3,0 & 95,5 & 3,94 & \multirow{3}{*}{$3,69(\mathrm{c})$} \\
\hline & 3 & 0,0 & 0,0 & 4,5 & 31,8 & 63,6 & 3,59 & \\
\hline & 10 & 0,0 & 1,5 & 3,0 & 34,8 & 60,6 & 3,55 & \\
\hline \multirow{3}{*}{ Thiophanate-methyl } & 1 & 0,0 & 0,0 & 1,5 & 7,6 & 90,9 & 3,89 & \multirow{3}{*}{$3,81(\mathrm{c})$} \\
\hline & 3 & 0,0 & 0,0 & 3,0 & 9,1 & 87,9 & 3,85 & \\
\hline & 10 & 0,0 & 0,0 & 4,5 & 19,7 & 75,8 & 3,71 & \\
\hline \multirow{3}{*}{ Prochloraz } & 1 & 0,0 & 100,0 & 0,0 & 0,0 & 0,0 & 1,00 & \multirow{3}{*}{$0,81(a b)$} \\
\hline & 3 & 3,0 & 97,0 & 0,0 & 0,0 & 0,0 & 0,97 & \\
\hline & 10 & 53,0 & 47,0 & 0,0 & 0,0 & 0,0 & 0,47 & \\
\hline \multirow{3}{*}{ Cyproconazole } & 1 & 3,0 & 43,9 & 34,8 & 4,5 & 13,6 & 1,82 & \multirow{3}{*}{$1,10(a b)$} \\
\hline & 3 & 15,2 & 66,7 & 18,2 & 0,0 & 0,0 & 1,03 & \\
\hline & 10 & 53,0 & 47,0 & 0,0 & 0,0 & 0,0 & 0,47 & \\
\hline \multirow{3}{*}{ Epoxiconazole } & 1 & 1,5 & 90,9 & 7,6 & 0,0 & 0,0 & 1,06 & \multirow{3}{*}{0,60 (a) } \\
\hline & 3 & 66,7 & 33,3 & 0,0 & 0,0 & 0,0 & 0,33 & \\
\hline & 10 & 59,1 & 40,9 & 0,0 & 0,0 & 0,0 & 0,41 & \\
\hline \multirow{3}{*}{ Flusilazole } & 1 & 3,0 & 47,0 & 34,8 & 7,6 & 7,6 & 1,70 & \multirow{3}{*}{$1,12(a b)$} \\
\hline & 3 & 7,6 & 87,9 & 4,5 & 0,0 & 0,0 & 0,97 & \\
\hline & 10 & 30,3 & 69,7 & 0,0 & 0,0 & 0,0 & 0,70 & \\
\hline \multirow{3}{*}{ Tebuconazole } & 1 & 1,5 & 25,8 & 40,9 & 21,2 & 10,6 & 2,14 & \multirow{3}{*}{$1,42(a b)$} \\
\hline & 3 & 10,6 & 57,6 & 22,7 & 7,6 & 1,5 & 1,32 & \\
\hline & 10 & 21,2 & 74,2 & 4,5 & 0,0 & 0,0 & 0,83 & \\
\hline \multirow{3}{*}{ Tetraconazole } & 1 & 4,5 & 25,8 & 57,6 & 12,1 & 0,0 & 1,77 & \multirow{3}{*}{$1,30(a b)$} \\
\hline & 3 & 7,6 & 62,1 & 30,3 & 0,0 & 0,0 & 1,23 & \\
\hline & 10 & 15,2 & 77,3 & 7,6 & 0,0 & 0,0 & 0,92 & \\
\hline \multirow{3}{*}{ Fenpropimorph } & 1 & 0,0 & 69,7 & 30,3 & 0,0 & 0,0 & 1,30 & \multirow{3}{*}{$1,08(a b)$} \\
\hline & 3 & 1,5 & 98,5 & 0,0 & 0,0 & 0,0 & 0,98 & \\
\hline & 10 & 3,0 & 97,0 & 0,0 & 0,0 & 0,0 & 0,97 & \\
\hline & 1 & 1,5 & 15,2 & 13,6 & 42,4 & 27,3 & 2,79 & \\
\hline Azoxystrobin & 3 & 12,1 & 34,8 & 39,4 & 12,1 & 1,5 & 1,56 & $1,78(a b)$ \\
\hline & 10 & 24,2 & 53,0 & 21,2 & 1,5 & 0,0 & 1,00 & \\
\hline & 1 & 3,0 & 25,8 & 10,6 & 28,8 & 31,8 & 2,61 & \\
\hline Kresoxim-methyl & 3 & 3,0 & 24,2 & 24,2 & 36,4 & 12,1 & 2,30 & $2,22(b)$ \\
\hline & 10 & 9,1 & 37,9 & 28,8 & 15,2 & 9,1 & 1,77 & \\
\hline & 1 & 10,6 & 63,6 & 25,8 & 0,0 & 0,0 & 1,15 & \\
\hline Pyraclostrobin & 3 & 16,7 & 75,8 & 7,6 & 0,0 & 0,0 & 0,91 & $0,96(a b)$ \\
\hline & 10 & 16,7 & 83,3 & 0,0 & 0,0 & 0,0 & 0,83 & \\
\hline & 1 & 1,5 & 27,3 & 36,4 & 25,8 & 9,1 & 2,14 & \\
\hline Cyprodinil & 3 & 4,5 & 75,8 & 19,7 & 0,0 & 0,0 & 1,15 & $1,40(a b)$ \\
\hline & 10 & 7,6 & 90,9 & 1,5 & 0,0 & 0,0 & 0,94 & \\
\hline
\end{tabular}

Stopień wrażliwości izolatów podany w skali 0-4 wyrażającej stosunek wielkości kolonii rosnącej na podłożu z fungicydem do kolonii kontrolnej rosnącej na czystej pożywce PDA, 0 - izolaty bardzo wrażliwe, 1 - wrażliwe (1-20\%), 2 - średnio wrażliwe (21-50\%), 3 - odporne (51-80\%), 4 - wysoce odporne (> 81\%). Wyniki testu Tukeya - substancje czynne ograniczające wzrost badanych izolatów: a - bardzo dobrze, ab - dobrze, $\mathrm{b}$ - średnio, c - niewystarczająco

PDA medium, 0 - isolates highly sensitive, 1 - sensitive (1-20\%), 2 - medium sensitive (21-50\%), 3- resistant (51-80\%), 4- highly resistant (> 81\%). Tukey test results - active substances limited grown tested isolates: a - very well, ab - well, b-medium, c - indifferently 
Blisko $100 \%$ badanych izolatów M. graminicola było odpornych lub wysoce odpornych na tiofanat metylu i karbendazym, dodane do pożywki w stężeniu 1, 3 lub 10 ppm (średnie stopnie wrażliwości 3,81 i 3,69) (tab. 1). Możliwość uodparniania się szczepów M. graminicola na benzimidazole sygnalizowana była już w latach 80 . XX wieku (Griffin i Fisher 1985). Przeprowadzone badania wskazują na bardzo niską skuteczność tej grupy fungicydów w zwalczaniu septoriozy paskowanej liści pszenicy. Triazole należą do środków często stosowanych w zwalczaniu M. graminicola. Do substancji czynnych z grupy triazoli charakteryzujących się najwyższą skutecznością ograniczania wzrostu badanych izolatów $M$. graminicola należał epoksykonazol (średni stopień wrażliwości 0,60). Epoksykonazol dodany do pożywki w stężeniach 1,3 i 10 ppm powodował całkowite lub bardzo silne zahamowanie wzrostu większości badanych izolatów (92,4\% badanych izolatów bardzo wrażliwych lub wrażliwych na stężenie 1 ppm, a $100 \%$ na 3 i 10 ppm). Inne z badanych triazoli: cyprokonazol, flusilazol, tetrakonazol i tebukonazol również dobrze ograniczały wzrost liniowy badanych izolatów - średnie stopnie wrażliwości wynosiły odpowiednio: 1,10 ; 1,12; 1,30 i 1,42 (tab. 1). Część $z$ badanych izolatów charakteryzowała się jednak obniżoną wrażliwością na niektóre $\mathrm{z}$ badanych triazoli. Sumując: 18,1\% badanych izolatów było odpornych lub wysoce odpornych na cyprokonazol, $15,2 \%$ na flusilazol, $12,1 \%$ na tetrakonazol i aż $31,8 \%$ na tebukonazol dodane do pożywki w stężeniu 1 ppm (tab. 1). Wyższe stężenia substancji czynnych z grupy triazoli pozwalały na bardzo silne zahamowanie wzrostu badanych kolonii, jedynie $9,1 \%$ badanych izolatów było odpornych lub wysoce odpornych na tebukonazol obecny w podłożu w stężeniu $3 \mathrm{ppm}$. Dane literaturowe także wskazują na stopniowe uodparnianie się izolatów M. graminicola na triazole. Zjawisko to zachodzi stopniowo i triazole dotychczas nie straciły zdolności zwalczania septoriozy paskowanej liści pszenicy (Mavroeidi i Shaw 2005; Leroux i wsp. 2006, 2007; Stammler i wsp. 2008; Cools i wsp. 2011). Ze względu na szerokie stosowanie triazoli w ochronie zbóż prawdopodobne jest nasilenie się tego zjawiska także na terenie Polski. Bardzo dobrze wzrost liniowy izolatów $M$. graminicola ograniczał prochloraz (imidazol), średni stopień wrażliwości wynosił 0,81 . We wszystkich badanych stężeniach powodował on całkowite lub bardzo silne zahamowanie wzrostu badanych izolatów. W literaturze można znaleźć dane wskazujące jednak na możliwość zmniejszania wrażliwości $M$. graminicola na prochloraz (Mavroeidi i Shaw 2005), co nie zostało potwierdzone w przeprowadzonych badaniach. Strobiluryny obok triazoli należą do substancji często stosowanych w ochronie zbóż przed septoriozą paskowaną liści pszenicy. Piraklostrobina należała do substancji ograniczających wzrost badanych izolatów M. graminicola w stopniu bardzo dobrym (średni stopnień wrażliwości 0,96). Dodanie do pożywki piraklostrobiny w stężeniach 1, 3 lub 10 ppm powodowało całkowite lub silne zahamowanie wzrostu u $100 \%$ badanych izolatów. Azoksystrobina i krezoksym metylu należały do substancji ograniczających wzrost liniowy badanych izolatów w stopniu dobrym lub średnim. Średnie stopnie wrażliwości $M$. graminicola izolatów dla w/w substancji wynosiły kolejno: 1,78 i 2,22. Ponad połowę badanych izolatów - 69,7\% (sumując ilość izolatów odpornych i wysoce odpornych) cechowała obniżona wrażliwości na azoksystrobinę, a 60,6\% na krezoksym metylu dodane do pożywki w stężeniu 1 ppm. Wzrost stężenia azoksystrobiny i krezoksymu metylu w pożywce do 3 ppm powodował spadek liczby izolatów charakteryzujących się obniżoną wrażliwością (izolaty odporne i wysoce odporne) do $13,6 \%$ dla azoksystrobiny i 48,5\% dla krezoksymu metylu. Zastosowanie w podłożu $10 \mathrm{ppm}$ stężenia w/w substancji czynnych spowodowało obniżenie liczby izolatów odpornych do $1,5 \%$ dla azoksystrobiny oraz $15,2 \%$ odpornych i 9,1\% wysoce odpornych dla krezoksymu metylu (tab. 1). Wzrost odporności izolatów M. graminicola na strobiluryny odnotowany był już w roku 2002 (Fraaije i wsp. 2003). Częstość występowania tego zjawiska związana jest $\mathrm{z}$ intensywnym wykorzystywaniem strobiluryn do ochrony upraw, prowadzonym w krajach zachodniej i południowej Europy (Stammler i wsp. 2012). Przeprowadzone badania wskazują, że skuteczne zwalczanie $M$. graminicola z wykorzystaniem fungicydów zawierających strobiluryny może stać się problemem także w Polsce. Wyniki te potwierdzają obserwacje $\mathrm{z}$ roku 2014, wskazujące na spadek skuteczności ich działania w hamowaniu wzrostu izolatów M. graminicola. Fenpropimorf (morfolina) i cyprodinil (anilino-pirymidyna) należały do substancji ograniczających wzrost badanych izolatów $M$. graminicola w stopniu dobrym. Średnie stopnie wrażliwości izolatów dla w/w substancji wynosiły kolejno 1,08 i 1,40. Dodanie do pożywki fenpropimorfu w stężeniu $1 \mathrm{ppm}$ powodowało całkowite lub silne zahamowanie wzrostu u 69,7\%, a 3 lub 10 ppm $100 \%$ badanych izolatów. Odpornych na cyprodinil w stężeniu 1 ppm było 25,8\%, a wysoce odpornych 9,1\% badanych izolatów, jednocześnie $28,8 \%$ izolatów było wrażliwych lub bardzo wrażliwych. Zastosowanie cyprodinilu w stężeniu 3 ppm spowodowało całkowite lub silne zahamowanie wzrostu u 80,3\%, a 10 ppm u 98,5\% badanych izolatów.

$\mathrm{Na}$ podstawie wyników wielokrotnego testu Tukeya można stwierdzić na poziomie istotności 0,05 , że badane izolaty charakteryzowały się dużą zmiennością średnich stopni wrażliwości na badane substancje czynne fungicydów. Zostały one podzielone na płynnie zachodzące na siebie grupy. Do grupy związków bardzo dobrze (a) i dobrze (ab) ograniczających wzrost badanych izolatów M. graminicola zaklasyfikowane zostały wszystkie substancje czynne z grupy: triazoli, prochloraz, fenpropimorf, cyprodinil, piraklostrobina i azoksystrobina. W kolejnych grupach średnio (b) lub niewystarczająco (c) ograniczających wzrost izolatów $M$. graminicola znalazły się krezoksym metylu (b) oraz benzimidazole - karbendazym i tiofanat metylu (c) (tab. 1).

\section{Wnioski / Conclusions}

1. Najwyższą skutecznością ograniczania wzrostu izolatów $M$. graminicola charakteryzowały się: epoksykonazol (triazol), prochloraz (imidazol), piraklostrobina (strobilurina) i fenpropimorf (morfolina). 
2. Większość badanych izolatów $M$. graminicola była odporna na substancje czynne z grupy benzimidazoli karbendazym i tiofanat metylu.

3. Wśród badanych izolatów M. graminicola zidenty- fikowano szczepy o obniżonej wrażliwości na: triazole (cyprkonazol, flusilazol, tebukonazol i tetrakonazol), strobiluryny (azoksystrobina i krezoksym metylu) oraz cyprodinil (anilino-pyrimidyna).

\section{Literatura / References}

Cools H.J., Mullins G.L., Fraaije B.A., Parker J.E., Kelly D.E., Lucas J.A., Kelly S.L. 2011. Impact in recently emerged sterol 14-demethylase (CTP51) variants of Mycosphaerella graminicola on azole fungicide sensitivity. Applied and Environmental Microbiology 77: 3830-3837.

Eriksen L., Munk L. 2003. The occurrence of Mycosphaerella graminicola and its anamorph Septoria tritici in winter wheat during the growing season. European Journal of Plant Pathology 109: 253-259.

Eyal Z. 1999. The Septoria tritici and Stagonospora nodorum blotch diseases of wheat. European Journal of Plant Pathology 105: $629-641$.

Fraaije B.A., Lucas J.A., Clark W.S., Burnett F.J. 2003. QoI resistance development in populations of cereal pathogens in the UK. The BCPC International Congress - Crop Science and Technology 2: 689-694.

FRAC 2013. List of plant pathogen organisms resistant to disease control agents. Revised January 2013. Avaible from: www.frac.info [Accessed: 27.10.2014].

Głazek M., Sikora H. 1998. The occurrence of Septoria tritici and its teleomorph Mycosphaerella graminicola in the region of Upper Silesia in 1996. Journal of Plant Protection Research 38 (1): 23-29.

Griffin M.J., Fisher N. 1985. Laboratory studies on benzimidazole resistance in Septoria tritici. Bulletin OEPP/EPPO Bulletin 15: 505-512.

Leroux P., Albertini C., Gautier A., Gredt M., Walker A.S. 2007. Mutation in the CYP51 gene correlated with changes in sensitivity to sterol 14a-demethylation inhibitors in field isolates of Mycosphaerella graminicola. Pest Management Science 63: 688-698.

Leroux P., Walker A.S., Albertini C., Gredt M. 2006. Resistance to fungicides in French populations of Septoria tritici, the causal agent of wheat leaf blotch. Fungicide resistance: are we winning the battle but losing the war? Aspects of Applied Biology 78: 153-162

Mavroeidi V.I., Shaw M.W. 2005. Sensitivity distributions and cross-resistance patterns of Mycosphaerella graminicola to fluquinconazole, prochloraz and azoxystrobin over a period of 9 years. Crop Protection 24: 259-266.

Mirzwa-Mróz E., Tvaruzek L., Zamorski C., Nowicki B. 2005. Research on the development of Mycosphaerella graminicola (Fuckel) Schroeter teleomorph on wheat leaves from Poland and Czech Republic. Acta Agrobotanica 58 (1): $59-65$.

Stammler G., Carstensen M., Koch A., Semar M., Strobel D., Schlehuber S. 2008. Frequency of different CYP51-haplotypes of Mycosphaerella graminicola and their impact on epoxiconazole -sensitivity and field efficacy. Crop Protection 27: 1448-1456.

Stammler G., Taher K., Koch A., Haber J., Liebmann B., Bouagila A., Yahyaoui A., Nasraoui B. 2012. Sensitivity of Mycosphaerella graminicola isolates from Tunisia to epoxiconazole and pyraclostrobin. Crop Protection 34: 32-36.

Suffert F., Sache I., Lannou C. 2011. Early stages of Septoria tritici blotch epidemics of winter wheat: build-up, over seasoning, and release of primary inoculum. Plant Pathology 60: 166-177. 